\title{
The Relationship between Work Values and the Staff Behaviour in Islamic-based Higher Learning Institutions in Malaysia
}

\author{
Osman Md Rasip", Nazri Muslim,", Siti Arni Basir¹, Raja Hisyamuddin Raja Sulong1, \\ Mohamad Hakki Bawadi ${ }^{3}$ \\ ${ }^{1}$ Department of Siasah Syar'iyyah, Academy of Islamic Studies, Universiti of Malaya, Malaysia \\ ${ }^{2}$ Pusat CITRA, Universiti Kebangsaan Malay sia, Malay sia \\ ${ }^{3}$ Department of Human Resource, Ingress Auto Sdn Bhd, Malay sia
}

Received February 10, 2020; Revised March 19, 2020; Accepted March 28, 2020

Copyright $\odot 2020$ by authors, all rights reserved. Authors agree that this article remains permanently open access under the terms of the Creative Commons Attribution License 4.0 International License

\begin{abstract}
Organizational behaviour literature reveals that the aspect of work values has a significant relationship with staff behavior, such as organizational commitment, job satisfaction and intention to quit. This study was conducted to explore the relationships within the context of academic staff in selected Islamic Institutions of Higher Learning in Malaysia. The result of the correlation test of 354 samples of academic staff from seven Islamic higher education institutions revealed that work values have a significant relationship with staff behaviour. This study focuses on the probability sampling where a certain population was identified and next, the sample was taken to the represent population. The correlation came in the form of the descriptive statistics through a close observation of the variables. Next, the hypothesis study through the testing on quantitative assumptions based on the relationship identified to answer the many questions emerging in the study. This study carries new outcomes with empirical evidence about the roles of work values with staff behaviour particularly in selected Islamic Institutions of Higher Education in Malaysia. In general, the outcome of the study indicated that the independent variable, which is Work Value had a relationship and influenced staff behaviour comprising of work satisfaction, commitment and the intention to quit. From several main findings, it can be seen that Work Values play an important role towards staff behaviour. The study finding showed that several components of work values like stimu lation of thoughts, freedom, diverse tasks and creativity are very important to academic staff when it comes to carrying out their duties. Thus, Higher Learning Institutions may re in the Work Value test as a prerequisite before candidates are accepted as the academic staff.
\end{abstract}

Keywords Work Values, Staff Behaviour, Islamic Based Higher Learning Institutions, Human Capital, Malaysia

\section{Introduction}

The human capital in an organisation is undeniably an important asset that fuels the productivity and determines the quality of the organisational activities. As an important element, it supplies an organisation with manpower, talent and innovative skills. Thus, human capital must be managed systematically and effectively so that this dominating factor can give an optimal impact to the development of the organisation. In this milennial era, organisations always have to confront a diverse set of challenges that require a great effort in enhancing performance excellence and promising productivity through quality human capital. An organisation that is incapable of rendering optimal human capital will lag behind and is not fit to compete. The concept of human capital management focuses on the asset value whereby the contribution of highly performing employees leads to enhanced productivity and an effective organisation. One of the elements of human capital that must be consistent with the organisational objective is the staff's own work values. Robbins [1] state that the manager or the leader plays a significant role in determining the behaviour and performance of the staff also the effectiveness of the organisation. There is also an association between effectiveness and the capability to sustain and influence the group effectively. 


\section{Problem Statement}

In Malaysia, education is the sector that has consistently drawn the attention of the government. This is evident through the budget allocation of this sector; for example, for the period of 2006-2010 in the Ninth Malaysia Plan, the government has allocated $20.6 \%$ out of the whole RM200 billion of the budget to the education sector. This is because higher education is the best channel for generating quality human capital to achieve the status of developed country in 2020. The government endorses the position of Higher Learning Institutions (HLI) as the hub of knowledge as a significant contribution to the development of the country's socio-economy and the development of its human capital. To date, HLI have grown exponentially with an increasing number of students and various study programs. Together with the fast rate of globalisation, the government anticipates that HLI would continue to be competitive and durable in order to remain the best universities in the world. The effort to increase the capability of HLI is done continuously to implement the function and responsibility more effectively, more transparently and more effectively towards producing an excellent higher education system[2].

The government strives to empower and increase the quality of national higher education to achieve the international status. In this vein, local higher education institutions are benchmarked according to the international standard and the grading system is introduced. Higher learning institutions have to abide by the quality assurance procedure standard dictated by the Malaysian Qualification Frame work (MQF). To support the implementation of $\mathrm{MQF}$ and to create an integrated quality assurance system, the government has set up the Malaysian Qualification Agency in 2006. The establishment of this agency is hoped to be able to control and monitor the standard of the public and private higher learning institutions" quality as well being able to improve the quality of the universities and their academicians at an international standard. The government has set up the National Higher Education Institutions (IPPTN) on 21 August 2007 hosted by Universiti Sains Malaysia. This institution is given the responsibility in several aspects of the development of HLI in this country. A mong the roles that have been outlined are related to studies of higher learn ing centers' curriculum, good management in IPT, a sustainable national higher education system that has a role in developing human capital especially the work development of the academicians and the strategic plan of the national higher education [3].

The government also introduced an upgrading of the APEX University from the list of HLI implemented in 2008. Other than that, the high commitment of the government in empowering HLI is evident with the target of at least three (3) HLI being acknowledged as among 100 universities and one of 50 famous universities in the world in 2020. Other than that, HLI has at least 75 percent of academic staff who hold $\mathrm{PhD}$ and all HLI are given the autonomous rights when they achieve the target of income generation stipulated [4]. In the effort to strengthen the capability and the credibility of HLI, the quality of the academic staff is enhanced by encouraging the lecturers to further their studies at $\mathrm{PhD}$ and post-doctoral levels. Also, related training and courses are provided to all the staff continuously. The government's determination can be seen in the establishment of the Higher Learning Leadership Academy (AKePT) at the end of 2007 in preparation of training in management and leadership, other than encouraging a good administrative practice. AKePT has the role of increasing the highest management leadership skills in HLI other than creating the culture of professionalism and the quality also improving the aspect of pedagogy among the lecturers. Nevertheless, several AKePT leadership programs have been implemented with the purpose to produce an effective HLI leadership and the line of educators who can understand the aspects of excellence and innovation.

The development of Islamic-based higher learning institutions should be parallel with the development of higher learning education in this country. A number of Islamic-based higher learning institutions in this country include Universiti Islam Antarabangsa Malaysia (UIAM), Universiti Sains Islam Malaysia (USIM), Kolej Universiti Islam Antarabangsa Selangor (KUIS) and many others. The advantage of the Islamic higher learning institutions is that the knowledge offered is in the form of knowledge integration. Universiti Islam Antarabangsa Malaysia for instance places the concept of knowledge integration in the university mission which is:

"Taking special and great responsibilities to form the mentality of the contemporary Muslims and to integrate the knowledge of the decree and humanity science with a positive approach." and "To produce a quality, professional, scholar by integrating the quality of imaan, knowledge and morality by giving service as a comprehensive agent and development at par with the sustainable development in Malaysia and in the Islamic world".

A good, noble mission must be generated through excellent human capital who are able to be independent especially through the role of efficacious, disciplined and ethical educators. Various programs and courses are prepared by the higher learning institutions from certificate and diploma courses right to the doctoral level. To render success to the program, the main focus lies in the human capital which is committed educators who have high level of work involvement. This is harmonious with the demand of labour force in multiple sectors that has been well progressing in this country. The higher learning system needs to ensure that HLI can build their reputation with a dynamic, competitive capabilities, as well as ab le to pred ict the forthcoming challenges and are prepared to act effectively. A mong the characteristics of world-renowned 
HLI are their fascinating success stories, the fact that they can sustain the best academicians who can contribute significantly to the growth of research, produce scholars who can master and practice the knowledge learned at the expense of the local, national and international communities [5].

The government has several core objectives in the effort to empower HLI where it needs to make sure that the HLI management system is efficacious, effective and transparent towards the autonomy and to strengthen the leadership and the highest manage ment of HLI. The core objectives also include to acclimate a sense of professionalism and intellectualis $\mathrm{m}$ among academicians so that they give excellent services, and for HLI to have a conducive environment alongside the best learning, teaching and research facilities.

In the effort to increase the performance of the academic staff, it is important for the responsible parties to know the basic factors that lead to optimal staff behaviour and performance. It cannot be denied that higher learning institutions or responsible bodies have carried out a lot of training, courses, campaigns and so on to boost the commitment and performance of their staff. That said, the improvement and balance programs carried out have been found to be unsuccessful in increasing the work satisfaction and commitment of the educators, if the stimulating and motivating factors are not taken into account. It involves the considering the basic factor of the individual principle which is the Work Values, whether intrinsically or extrinsically.

Work Values are essential in the aspect of increasing the work motivation involving staff behaviour. Work Values give a significant contribution to staff behaviour. Despite the fact that the studies on staff behaviour like the commitment to organisation, wo rk satisfaction, employees' loyalty and work involvement are actively conducted in the discipline of human resource management and organisational behaviour but the studies on its relationship with Work Values have been scarce [6]. What is more, previous studies show that the outcomes have been mixed between one another. Meanwhile, a lot of researchers agree about the importance of value in observing human behaviour.

Dawis [7] states that values are the criteria or standard where individuals see something that gives a significance or not to him or her, depending on the values upheld. Someone with certain Work Values will influence the attitude towards his or her daily tasks or work. In the effort to understand staff behaviour, it is important to identify and understand the relationship between values, attitude and behaviour [8]. Individual work is made consistent with the Work Values, interest, talent and ability so that it will reach optimal potential. Siti Arni et.al [9] emphasise on the importance of the role of the leaders in inculcating values and ethics in a competitive organisation.

Value also refers to the standard that drives individual behaviour towards his work and this will leave an impact to his behaviour in the organis ation. Work Values held within emp loyees will govern their behaviour and attitude that can lead to the organisational success [10]. Although a lot of researchers [11] exp lain the importance of Work Values to the organisation, the studies on it are still very little, compared to the need to understand it better in the context of its as sociation with organis ational behaviour.

Past studies have found that employees who are not happy with work, can influence their change in attitude and behaviour, like the commitment to the organisation and work performance. In the work satisfaction model, most scholars opine that intrinsic work satisfaction, extrinsic work satisfaction, commitment towards the organisation and work involvement are different constructs but inter-related. For example, the ability of the manager to manage work will increase employees' satisfaction intrinsically and extrinsically, and further increase their commitment to the organis ation [12].

When employees feel appreciated in their work, they are more willing to get involved and contribute more to their organisation be it in the form of time, energy and opinion. However, if they have the willingness to get involved in their work and strive to make the mission and the organisational goals succeed and yet the organisation fails to give them that opportunity, they will become less productive and will withdraw from the mainstream organisation and slowdown in their involvement in the organisation. Next, when employees are not given the opportunity to cater to something that is felt to be important and valuable, they will be likely to leave the organisation.

\section{Study Hypothesis}

Hypothesis 1: Work Values have a significant relationship with work satisfaction.

Hypothesis 2: Work Values have a significant relationship with the commitment towards the organisation.

Hypothesis 3: Work Values have a significant relationsh3. ip with the desire to quit.

\section{Study Methodology}

This study was conducted among academic staff in selected Islamic higher learning institutions in the Peninsula Malaysia. The aim of the study was to identify and understand several relationships between the Work Values as the independent variable, and the Staff Behaviour as the dependent variable. This study was conducted in the form of cross-sectional survey as the data was only taken once and collected in a certain period of time based on the site work that used the questionnaire method [13]. This study focused on the probability sampling where a certain population was identified and next, the sample was taken to represent the population. The correlation came in the form of the descriptive statistics 
through a close observation of the variables. Next, the hypothesis study through the testing on quantitative ass umptions based on the relationship identified to answer the many questions emerging in the study [14].

\section{Study Population and Sample}

The study population was 3216 acade mic staff in seven institutes/Islamic higher learn ing academies. The sample size was determined based on the sample of Krjecie and Morgan [15] which is the population up to 3500 people, and the sample size must be 300 respondents. Meanwhile, the number of sample $10 \%$ to $20 \%$ from the population would be sufficient. 354 questionnaire forms were complete and through the screening process to be the sample in this study.

\section{Instrument Source}

Table 1. Source of Instrument

\begin{tabular}{|l|l|l|l|}
\hline Variables & Component & Item & Source \\
\hline Work values & 10 & 36 & Super (1970) dan Elizur (1996). \\
\hline Commitment towards organisation & 1 & 7 & Porter, Mowday dan Strees (1979). \\
\hline Work satisfaction & 1 & 9 & Herzberg (1968); Azman (2009). \\
\hline The intention to quit & 1 & 5 & Wayne, Shore \& Liden (1997). \\
\hline
\end{tabular}

\section{Analysis Method}

The questionnaire forms received from the respondents in this pilot study have been analysed using the Statistical Package for the Social Science (SPSS) version 11. All the scales used in the study were tested with the reliability analysis through the SPSS packages. Previously, the data were screened to check on the data normality, linearity and homoscedasticity. Next, the descriptive statistics was used to explain about the demographics of the variables. The reliability test was adopted to measure the consistency in the reliability analysis. The Alpha Cronbach value that approaches the alpha value of 1 shows the highest degree of the internal consistency for the construct reliability used.

The correlation analysis used to measure the strength of the relationship between independent and dependent variables. The correlation analysis shows the coefficient correlation and the degree of magnitude of the relationship between two variables. The Pearson correlation analysis is used to test and determine the significant relationship between work values and staff behaviour.

\section{Validity and Reliability Tests}

Table 2. The results of the validity and reliability of the measurement scale.

\begin{tabular}{|c|c|c|c|c|c|c|c|}
\hline Variable & $\begin{array}{c}\text { No of } \\
\text { Item }\end{array}$ & $\begin{array}{c}\text { Analysis Factor } \\
\text { Value }\end{array}$ & KMO & $\begin{array}{c}\text { Sferasiti Bartlett } \\
\text { Test }\end{array}$ & $\begin{array}{c}\text { Eigen } \\
\text { Value }\end{array}$ & $\begin{array}{c}\text { Explanation } \\
\text { of Variant }\end{array}$ & $\begin{array}{c}\text { Alpha Cronbach } \\
\text { Value }\end{array}$ \\
\hline Work values & 36 & $0.51-0.65$ & 0.811 & $\begin{array}{c}938,679 \\
\mathrm{p}=.000\end{array}$ & 3.7 & 37.346 & 0.72 \\
\hline $\begin{array}{c}\text { Commitment towards } \\
\text { organisation }\end{array}$ & 7 & $0.54-0.70$ & 0.716 & $\begin{array}{c}453.387 \\
\mathrm{p}=.000\end{array}$ & 2.5 & 36.063 & 0.63 \\
\hline Work satisfaction & 9 & $0.51-0.73$ & 0.838 & 1108.655 & 3.7 & 41.902 & 0.63 \\
\hline The intention to quit & 5 & $0.77-0.85$ & 0.833 & 1163.465 & 3.3 & 66.377 & 0.83 \\
\hline
\end{tabular}

Table 3. The correlation between independent and dependent variables.

\begin{tabular}{|l|l|l|l|l|}
\hline Construct & 1 & 2 & 3 & 4 \\
\hline$(1)$ work values & 1 & $.206^{* *}$ & $.384^{* *}$ & $-.326^{* *}$ \\
\hline (2) commitment & $.206^{* *}$ & .1 & $.489^{* *}$ & $-.132^{* *}$ \\
\hline (3) work satisfaction & $.384^{* *}$ & $.489^{* *}$ & 1 & $-.556^{* *}$ \\
\hline (4) the intention to quit & $-.326^{* *}$ & $-.251^{* *}$ & $-.556^{* *}$ & 1 \\
\hline
\end{tabular}

** Correlation is significant at significant level 0.01 (2-tails)

* Correlation is significant at significant level 0.05 (2-tails) 


\section{The Correlation between Components of Work Values and Work Satisfaction}

The correlation test between components of Work Values and work satisfaction found that 8 out of 10 components of Work Values correlate with work satisfaction at significance level of 0.01 . However, as a whole, the correlation level was weak although the relationship is significant. Only 2 components had the correlation level more than 0.300 which was thought stimulation $(\mathrm{r}=.304)$ and diversity of tasks $(\mathrm{r}=.348)$. The results of the correlation of other components were as follows:

Table 4. Correlation between components of Work Values and Work Satisfaction

\begin{tabular}{|c|c|c|c|c|c|c|c|c|c|c|c|}
\hline Component & 1 & 2 & 3 & 4 & 5 & 6 & 7 & 8 & 9 & 10 & 11 \\
\hline $\begin{array}{l}\text { (1)readiness to } \\
\text { help }\end{array}$ & 1 & & & & & & & & & & \\
\hline (2)achievement & $.246 * *$ & 1 & & & & & & & & & \\
\hline $\begin{array}{l}\text { (3)stimulation of } \\
\text { thought }\end{array}$ & $.389 * *$ & $.228 * *$ & 1 & & & & & & & & \\
\hline (4)freedom & .022 & $.182 * *$ & $.175 * *$ & 1 & & & & & & & \\
\hline (5)prestige & $.198 * *$ & $.220 * *$ & $.379 * *$ & $.262 * *$ & 1 & & & & & & \\
\hline (6)work assurance & $.281 * *$ & $.162 * *$ & $.372 * *$ & $.198 * *$ & $.452 * *$ & 1 & & & & & \\
\hline (7)colleagues & $.362 * *$ & $.193 * *$ & $.250 * *$ & $.243 * *$ & $.354 * *$ & $.472 * *$ & 1 & & & & \\
\hline (8)creativity & $.277 * *$ & $.153 * *$ & $.572 * *$ & $.192 * *$ & $.324 * *$ & $.475 * *$ & $.403 * *$ & 1 & & & \\
\hline (9)family career & $.246 * *$ & $.258 * *$ & .093 & $.242 * *$ & $.144 * *$ & $.219 * *$ & $.373 * *$ & $.214 * *$ & 1 & & \\
\hline (10)diversity & $.389 * *$ & $.312 * *$ & $.472 * *$ & $.242 * *$ & $.325 * *$ & $.381 * *$ & $.430 * *$ & $.550 * *$ & $.433 * *$ & 1 & \\
\hline $\begin{array}{l}\text { (11)work } \\
\text { satisfaction }\end{array}$ & $.550 * *$ & $.161 * *$ & $.304 * *$ & .044 & $.201 * *$ & $.226 * *$ & $.292 * *$ & $.299 * *$ & $.259 * *$ & $.348 * *$ & 1 \\
\hline
\end{tabular}

** Correlation is significant at significant level 0.01 (2-tail)

* Correlation is significant at significant level 0.05 (2-tail)

\section{Correlation between Components of Work Values and Organisational Commitment}

The correlation analysis between components of Work Values and organisational commitment showed that 7 out of 10 components of Work Values correlate significantly at significance level 0.01. However, the correlation value was low for example the component ready to help ( $\mathrm{r}=.285)$, creativity $(\mathrm{r}=.235)$ and diversity of tasks $(\mathrm{r}=.245)$.

\section{Correlation between Components of Work Values and the Intention to Quit}

The correlation test carried out towards the components of Work Values and the intention to quit showed that 8 out of 10 components of Work Values correlates with the intention to quit at significance level 0.01 . The whole components of Work Values corre late at low value, a mong which are the readiness to help $(\mathrm{r}=-.230)$, freedom $(\mathrm{r}=-.126)$, stimulation of thoughts (r=-.259). Only the component Work Assurance showed a moderate correlation $(\mathrm{r}=-.353)$.

Table 5. Correlation between components of Work Values and the intention to quit.

\begin{tabular}{|c|c|c|c|c|c|c|c|c|c|c|c|}
\hline Component & 1 & 2 & 3 & 4 & 5 & 6 & 7 & 8 & 9 & 10 & 11 \\
\hline (1) readiness to help & 1 & & & & & & & & & & \\
\hline (2) achievement & $.246 * *$ & 1 & & & & & & & & & \\
\hline (3) stimulation thought & $.389 * *$ & $.228 * *$ & 1 & & & & & & & & \\
\hline (4) freedom & .022 & $.182 * *$ & $.175 * *$ & 1 & & & & & & & \\
\hline (5) prestige & $.198 * *$ & $.220 * *$ & $.379 * *$ & $.262 * *$ & 1 & & & & & & \\
\hline (6) work assurance & $.281 * *$ & $.162 * *$ & $.372 * *$ & $.198 * *$ & $.452 * *$ & 1 & & & & & \\
\hline (7)colleagues & $.362 * *$ & $.193^{* *}$ & $.250 * *$ & $.243 * *$ & $.354 * *$ & $.472 * *$ & 1 & & & & \\
\hline (8) Creativity & $.277 * *$ & $.153 * *$ & $.572 * *$ & $.192 * *$ & $.324 * *$ & $.475 * *$ & $.403 * *$ & 1 & & & \\
\hline (9) career family & $.171 * *$ & $.258 * *$ & .093 & $.242 * *$ & $.144 * *$ & $.219 * *$ & $.373 * *$ & $.214 * *$ & 1 & & \\
\hline (10) diversity & $.240 * *$ & $.312 * *$ & $.472 * *$ & $.242 * *$ & $.325 * *$ & $.381 * *$ & $.430 * *$ & $.550 * *$ & $.433 * *$ & 1 & \\
\hline (11) the intention to quit & $-.230 * *$ & -.079 & $-.259 * *$ & $-.126^{*}$ & -.099 & $-.353 * *$ & $-.266 * *$ & $-.162 * *$ & $-.175 * *$ & $-.228 * *$ & 1 \\
\hline
\end{tabular}

$* *$ Correlation is significant at significant level 0.01 (2-tail)

* Correlation is significant at significant level 0.05 (2-tail) 


\section{The Relationship between Work Values and Staff Behaviour}

The result of the Pearson correlation indicated that there was a significant relationship between Work Values and all components of staff behaviour tested namely work satisfaction, organisational commitment and the intention to quit. The study outcome has proven that there is a positive significant relationship between Work Values and work satisfaction and organisational commitment, also a negative significant relationship with the intention to quit.

This study outcome showed that Work Values act as the predictor to staff behaviour. However, the correlation level was moderate and weak. Acade mic staff in selected Is la mic higher learning institutions who have high Work Values showed a relationship with staff behaviour in terms of higher work satisfaction and better commitment to the organis ation also lower intention to quit.

A more profound study on the relationship between components of Work Values and Work Satisfaction indicated that the components task diversity and thought stimulation showed a correlation value to be at moderate level. The outcome depicts the suitability of the job scope of a lecturer involving various kinds of tasks like teaching, supervising, researching, consulting and liaising with government and private bodies and agencies, and so on. This aspect of task diversity enables academicians to use various kinds of skills and self-potential in completing their tasks. The academic staff of selected Islamic higher learning institutions also state that the aspect of task diversity existing in their job scope makes the work fascinating and they are not bound by any routine tasks only.

The job as a lecturer also requires a continuous activity of thought stimulation because of the many kinds of tasks that they have to do. The task of preparing teaching materials, for instance requires extensive reading, making analysis, synthes is and conclusion. Directly and indirectly, it will stimulate the thought and the ability to think. Research works that have become part of the main task for the lecturers also require academic ians to explore into new fields of study and unearth various issues. This necessitates academicians to continue perform the simulation of thoughts. These work values are in line with the scope and the work description of a lecturer.

This study found that the component work colleagues in the construct Work Values had a weak correlation with work satisfaction $(r=.292)$. This is because the main tasks of a lecturer such as teaching and completing the tasks, supervising students and giving consultation services are primarily done single-handedly. This is why colleagues are not the main factor that affects work satisfaction. Irrefutably there are also other tasks such as conducting research, attending faculty meetings, handling seminar programs, consultation sessions and so on still require cooperation and support from colleagues but they are not dominant factors on work satisfaction. According to the theory put forth by McClelland [16] related to the need to integrate individuals in an organisation, McClelland characterises individuals who have high requirement to collaborate usually are very eager to give assurance and agreement also appreciate their colleagues. They are also likely to listen to advice and make assessments and have an honest feeling to other people's feelings, compared to those who do not really stress on the need to work together. In the context of academic workforce that primarily works individually, the need to collaborate is less. This study is consistent with the previous study related to academic staff showing that the factor of colleagues has a small role to play towards work satisfaction among academic staff.

The study finding also showed that the component the readiness to help has a moderately high correlation with work satisfaction. The job scope as a lecturer that contributes to the widespread and development of knowledge through observation and research causes the aspect of the readiness to help to be in line with lecturers' work values. The teaching comes in the form of direct teaching to students in lecture halls, or indirectly through the study outcomes that can be used and that can benefit various agencies or the public at large. This readiness to help is also practiced in the selected Islamic-based higher learning institutions.

The component self-satisfaction from the construct Work Values als o correlated with self-s atisfaction although it was at low level. This finding is consistent with McClelland's criteria of needs outlining individual's criteria of achievement including the enthusiasm towards personal responsibility to solve problems on the work or tasks done. However, McClelland sees that emp loyees with high level of achievement are often associated with something that is difficult and challenging. If the work mostly involves routine tasks, self-achievement would be at low or moderate level.

It is also interesting to include that the component prestige did not have any significant re lationship with staff behaviour. This finding was different from several past studies. A significant relationship between the construct Prestige and Work Satisfaction. Possibly, lecturers in Is la mic higher learning institutions see the job of a lecturer as no more prestigious as other jobs. What is more important is to do the work honestly and ethically [17].

It was also found that the component freedom did not show any significant relationship with work satisfaction. Although lecturers have various tasks that can be done individually, lecturers are still bound by university regulations just like other employees. Academic staff for example, have to punch card or clock in and clock out like other support staff. Lecturer also have to prepare various documents and teaching reports regularly to fulfil the require ment of the monitoring body and to ensure quality. This heavy workload causes academic staff to feel that their freedom is limited. 
In terms of the relationship with the components of work values with the commitment to the organisation, almost all components had a significant correlation although the level was low. This study showed that work values correlate positively with the co mmit ment of the organis ation but also other factors like role of leadership.

This study discovered a significant negative relationship between Work Values and the intention to quit. High work values became the predictor to the low intention to quit. This study was in line with the work of Mobley [3] (1989) who listed down several factors causing employees to intend to leave their organisation. Some include work environment, the climate of the organisation, reward and benefit also offer to work somep lace else. The components of Work Values tested in this study like task diversity, relationship with colleagues, thought stimulation factor, and self-achievement gave an effect to the workers' intention to quit.

\section{Conclusions}

In general, the outcome of the study found that the independent variable which was Work Values has a relationship and influences staff behaviour comprising of work satisfaction, commitment and the intention to quit. From several main findings, it can be seen that Work Values play an important role towards staff behaviour. The study finding showed that several components of work values like stimu lation of thoughts, freedom, diverse tasks and creativity are very important to academic staff when it comes to carrying out their duties. Thus, HLI may make the Work Value test as a prerequisite before candidates are accepted as the academic staff. HLI can also hold courses and workshops about the necessary work values for the academic staff so that they will realise their responsibilities as lecturers that are increasingly demanding and challenging, and so that they will no longer be in the traditional framework that advocates lecturers' duties to only surround delivering knowledge and teaching.

\section{REFERENCES}

[1] Robbins, S.P. Organizational Behavior. New Jersey: Prentice Hall. 2000

[2] Osman, Md Rasip. Kajian Faktor Yang Mempengaruhi Gelagat Kakitangan Di Institut Pengajian Tinggi Islam terpilih Di Malay sia, Tesis PhD, Universiti Malaya. 2013.

[3] Kementerian Pengajian Tinggi Malaysia. Buku Perangkaan Pengajian Tinggi Malaysia 2009: Kuala Lumpur. 2010.

[4] Kementerian Pengajian Tinggi Malay sia. Buku Perangkaan Pengajian Tinggi Malaysia 2009: Kuala Lumpur. 2010.

[5] Kementerian Pengajian Tinggi Malaysia. Buku Perangkaan
Pengajian Tinggi Malaysia 2009: Kuala Lumpur. 2010.

[6] Elizur, D. Work Values and job satisfaction. Psychological Reports, 69, 386-400. 1991; Ucanok, B. The effects of Work Values, Work value congruence and work centrality on organizational citizenship behavior, International Journal of Behavioral, Cognitive, Education and Psychological Sciences, 1(1), 1-14. 2008.

[7] Davis, D.. Business Research for Decision Making (4th Ed.). Belmont: Duxbury Press. 1996.

[8] Ucanok, B. The effects of Work Values, Work value congruence and work centrality on organizational citizenship behavior, International Journal of Behavioral, Cognitive, Education and Psychological Sciences, 1(1), 1-14. 2008.

[9] Siti Arni, Basir, Nurul Syafiqah, Mohd Zaid Abd Rahman, Monika@ Munirah. Peranan Pemimpin dalam Pelaksanaan Etika Kerja Islam: Kajian Kes di Johor Corporation (JCorp) Jurnal Usuluddin, 44 (Julai -Disember 2016): 45-83. 2016.

[10] Brown D. The role of work and cultural values in occupational choice, satisfaction and success: a theoretical statement, Journal of Counseling and Development, 80(1), 48-56. 2002.; Rokeach, M. The Nature of Human Values, New York: Free Press. 1973.

[11] Super, D. The Work Values Inventory. Boston: Houghton-Mifflin. 1970.; Rokeach, M. The Nature of Human Values, New York: Free Press. 1973.

[12] Randolph, D.S., \& Johnson, S.P. Predicting the effect of extrinsic and intrinsic job satisfaction factors on recruitment and retention of rehabilitation professionals. Journal of Healthcare Management. 50: 49-60. 2005.; Azman Ismail, Osman Md Rasip, Cindy John, Ali Boerhannoeddin, Wan Khairuzaman. Kepuasan Kerja Adalah Peramal Kepada Keinginan Berhenti Kerja Secara Sukarela: Satu Kajian Di Sebuah Penguasa Tempatan. Jurnal Kemanusiaan , Universiti Teknologi Malaysia, Bil 19 . 2011.

[13] Sekaran, U. Research Methods for Business: A Skill Building Approach, New York: John Wiley \& Sons, Inc. 2000.

[14] Sekaran, U. Research Methods for Business: A Skill Building Approach, New York: John Wiley \& Sons, Inc. 2000.

[15] Krejcie, R.V., \& Morgan, D.W. Determining sample size for research activities, Educational and Psychological Measurement, 30, 608. 1970.

[16] McClelland D. C. Testing for competence rather than intelligence, American Psychologist, 28. 1976.

[17] Elizur D. \& Koslowsky, M. Values and organisational commitment, International Journal of Manpower, 22(7), 593-599. 2000. 